\title{
Possibility of estimating reliability of diesel engines by applying the theory of semi-Markov processes and making operational decisions by considering reliability of diagnosis on technical state of this sort of combustion engines
}

\begin{abstract}
The paper presents semi-Markov models of technical state transitions for diesel engines, useful for determining reliability of the engines. A possibility of application of a three-state model with a simplified matrix function, or even a two-state model, to determine reliability of the engines, has been described herein on examples of known from literature semi-Markov models, for the case when appropriate diagnosing systems (SDG) are used to identify technical condition of the engines considered as diagnosed systems (SDN)). A risk function and a renewal (restitution) function have been proposed to apply for developing a two-state model of engine state transitions. An opportunity of considering reliability of diagnosis while making operational decisions by applying the statistical decision theory, has also been presented. Conditional probability $P\left(s_{i} / K_{i}\right)$ is recognized as a measure of reliability of diagnosis.
\end{abstract}

Key words: diagnostics, reliability, semi-Markov process, diesel engine, statistics, diagnosed system, diagnosing system, diagnostic system

\section{Możliwość oszacowania niezawodności silników o zapłonie samoczynnym z zastosowaniem teorii procesów semi-Markowa oraz podejmowania decyzji eksploatacyjnych z uwzględnieniem wiarygodności diagnozy o stanie technicznym tego rodzaju silników spalinowych}

W artykule przestawiono semimarkowskie modele zmian stanów technicznych silników o zpałonie samoczynnym, przydatne do określenia niezawodności tych silników. Wykazano, na przykładzie znanych z literatury modeli semimarkowskich, że możliwe jest zastosowanie do określenia niezawodności tych silników modelu trójstanowego o uproszczonej macierzy funkcyjnej a nawet modelu dwustanowego, w przypadku zastosowania odpowiednich systemów diagnozujacych (SDG) do identyfikacji stanu technicznego wspomnianych silników jako systemów diagnozowanych (SDN). Do opracowanie dwustanowego modelu zmian stanów silniów zaproponowano wykorzystanie funkcji ryzyka i funkcji intensywnosci odnowy (restytucji). Przedstwiono także możliwość uwzględnienia wiarygodności diagnozy przy podejmowaniu decyzji eksploatacyjnych w przypadku zastosowaia statystycznej teorii decyzji. Za miarę wiarygodności diagnozy przyjęte zostało prawdopodobieństwo warunkowe $P\left(s_{i} / \mathbf{K}_{\mathbf{i}}\right)$.

Słowa kluczowe: diagnostyka, niezawodność, proces semimarkowski, silnik o zapłonie samoczynnym, statystyka, system diagnozowany, system diagnozujacy, system diagnostyczny

\section{Introduction}

In the phase of operating marine diesel engines, particularly the main ones (engines employed in propulsion systems of ships), it is important to plan and control their operation. Planning requires having a knowledge of engine operation reliability to be expected during performance of transport tasks by a ship. In order to control the engine operation, when implementing the approved plan of operation, it is significant to know a complete diagnosis (instantaneous diagnosis, prognosis and genesis) that enables prediction of not only the technical state, but also the loads which engines under operation can be subjected to.
Considering the definitions of reliability of machines, provided in many publications [18, 21, 26], reliability of diesel engines can be defined in a similar way, as capability of the engines to convert energy in full range of loads, which they were fit to in the designing and manufacturing phases. And the probability of proper energy conversion for all performances in defined time and determined operating conditions can be recognized as a measure of such understood reliability of the engines $[2,4,12$, $21,26]$.

It can be assumed, like in publications [3, 6, 7], that any diesel engine works reliably if its technical condition can be classified to the class (set) of states of full ability and denoted as $s_{1}$. If the engine, due to its technical condition, cannot be loaded to 
the maximum extent, but only to the extent limited by the rated power value $[12,22]$, its state must be recognized as a state of partial ability $\left(s_{2}\right)$. When the engine, due to its significant wear, can be loaded only to the extent limited by the continuous operating power value $[12,22]$, it should be assumed that its technical state does not satisfy operating requirements and must be regarded as a state of disability $\left(s_{3}\right)$.

The mentioned technical states of this sort of engines and their time durations can be disclosed by using appropriate diagnosing systems (SDG), e.g. for marine engines, such as CoCoS (Computer Controlled Surveillance System) of MAN company, or CBM (Condition-Based Maintenance) of Wartsila company, videoskope of Everest company and others [20, 27, 28, 29]. Obtained through applying the technical diagnostics information on duration of state $s_{1}$ and the moment of losing it, as well as on the moments of occurring states $s_{2}$ and $s_{3}$, and their duration, enables application of the theory of semiMarkov processes for determining reliability of the engines $[6,7,8]$. When the systems $S D G$ are so improved that they enable development of a complete diagnosis $(p D G)$ comprising not only a reliable instantaneous diagnosis, but also prognosis of duration of state $s_{1}$, it is possible to obtain a transitions graph of engine states $s_{1}, s_{2}, s_{3}$, which is simplified in comparison to the graph described in publications $[5,7,11,25]$.

\section{Possible semi-Markov models of en- gine state transitions}

Building a semi-Markov model of a real process of technical state changes which proceed in the operating phase of a diesel engine, is a prerequisite for applying the theory of the semi-Markov processes. The properties of the models are as follows [4, 8, 19, 21, 23, 24]:

1) Markov condition is satisfied that future development of states of any engine (the process of technical state changes), for which the semi-Markov model was built, depends only on its state at the given time, not on engine functioning in the past, so that its future does not depend on the past, but on the present;

2) random variables $T_{i}$ (denoting the time duration of state $s_{i}$ regardless of which state is next) and $T_{i j}$ (denoting the time duration of state $s_{i}$, provided that the next state of the process is state $s_{j}$ ) have distributions different than exponential.

In the case of marine main engines it can be recognized that the Markov condition is satisfied because the following hypothesis was proved in researches [3, 7]: prognosing the technical state of any diesel engine at the time $\tau_{n}+t$, when only its state at the moment $\tau_{n}$ is known, is possible, because the engine state considered at any moment $\tau_{n}(n=0$, $1, \ldots, m ; \tau_{0}<\tau_{1}<\ldots<\tau_{m}$ ) indeed depends on the directly preceding state, not on the states that were before nor their time duration.

Additionally, the studies show that random variables like time of proper operation $\left(T_{u}\right)$ and renewal time $\left(T_{o}\right)$ of this sort of engines can be described with gamma and normal distributions, and the Weibull-Gniedenko distribution as well $[1,2,26]$.

Semi-Markov process is fully defined if its function matrix is known $[3,7,18]$

$$
\mathbf{Q}(\mathbf{t})=\left[Q_{i j}(t)\right]
$$

whose non-zero elements are interpreted as follows:

$$
\begin{aligned}
Q_{i j}(t) & =P\left\{W\left(\tau_{n+1}\right)=s_{j}, \tau_{n+1^{-}} \tau_{n}<t \mid W\left(\tau_{n}\right)=s_{i}\right\}= \\
& =p_{i j} F_{i j} ; s_{i}, \mathrm{~s}_{\mathrm{j}} \in S ; i, j=1,2, \ldots, n ; i \neq j
\end{aligned}
$$

where $p_{i j}$ - probability of state transition from $s_{i}$ to $s_{j}, F_{i j}$ - distribution of random variable $T_{i j}$, and when the initial distribution is given

$$
p_{i}=P\left\{W(0)=s_{i}\right\}, s_{i} \in S ; i=1,2, \ldots, n
$$

The paper [4] presents a model of state transition for diesel engines $\{W(t): t \geq 0\}$, whose values are elements of the set of classes (subsets) of technical conditions called states (which are of essential meaning in the operating practice):

$$
S=\left\{s_{i} ; i=1,2,3,4\right\}
$$

described as follows:

- $s_{1}$ - state of full (total) ability

- $s_{2}$ - state of partial (not full, not total) ability

- $s_{3}$ - state of disability for task,

- $s_{4}$ - state of full (total) disability.

Distinguishing states $s_{i} \in S(i=1,2,3,4)$ is very important for diesel engines as it is extremely significant to use them in state $s_{1}$, or $s_{2}$.

In this case the initial distribution of the process $\{W(t): t \geq 0\}$ is defined as follows:

$$
\begin{aligned}
& p_{1}=P\left\{W(0)=s_{1}\right\}=1 \cap p_{i}=P\left\{W(0)=s_{i}\right\}=0 \\
& \quad \text { for } i=2,3,4
\end{aligned}
$$

while its function matrix has the form:

$$
\mathbf{Q}(\mathbf{t})=\left[\begin{array}{cccc}
0 & Q_{12}(t) & 0 & 0 \\
Q_{21}(t) & 0 & Q_{23}(t) & 0 \\
Q_{31}(t) & 0 & 0 & Q_{34}(t) \\
Q_{41}(t) & 0 & 0 & 0
\end{array}\right]
$$

The model considers situations where the user can take the risk to perform the task when the engine finds in state $s_{2}$ and even take the risk to 
perform some tasks when its state is $s_{3}$. In the operating practice, it is difficult to distinguish unambiguously state $s_{1}$ from state $s_{2}$. This refers particularly to the case of deteriorating technical condition of marine main engine. This is due to the fact that external conditions (height, speed and direction of wave, speed and direction of wind, layer of seaweed and shellfish on the underwater section of hull, speed and direction of ocean currents, etc.) under which the sea-going vessels are operated and tasks are performed by users of the engines, significantly affect engine load changes [12, 22, 29]. In this operating situation, applying the diagnosing systems $(S D G)$ to identify technical conditions of shipborne main engines as diagnosed systems $(S D N)$ is easier when developing a tree-state set of technical states [4, 12, 22, 29]:

with interpretation:

$$
S=\left\{s_{1}, s_{2}, s_{3}\right\}
$$

- $s_{1}-$ state of engine full ability, which is recognized when the engine can be loaded in full range which was fit to in the designing and manufacturing phases,

- $s_{2}$ - state of engine partial ability, which occurs in the moment and proceeds when the engine cannot be loaded in the full range of engine performances, but can be loaded within the field not smaller than the range limited by the continuous power characteristic, however with no possibility of loading in the field of rotational speed overloads.

- $\quad s_{3}$ - state of engine disability, which occurs and proceed when the engine can be loaded only in the range below the continuous power characteristic, but also with no possibility of loading in the field of rotational speed overloads.

The described technical states $s_{i} \in S(i=1,2,3)$ are values of the process $\{X(t): t \geq 0\}$ of state transitions, with initial distribution, defined by the formula:

$$
P_{i}=P\left\{X(0)=s_{i}\right\}=\left\{\begin{array}{lll}
1 & \text { dla } & i=1 \\
0 & \text { dla } & i=2,3
\end{array}\right.
$$

and following function matrix:

$$
\mathbf{Q}(\mathbf{t})=\left[\begin{array}{ccc}
0 & Q_{12}(t) & Q_{13}(t) \\
Q_{21}(t) & 0 & Q_{23}(t) \\
Q_{31}(t) & 0 & 0
\end{array}\right]
$$

Application of an SDG enabling development of a reliable diagnosis [13, 15], allows implementation of the operation strategy, which includes preventive maintenance of the main engine when its state is recognized as $s_{2}$. This prevents damage to the engine during its work. Therefore, the stochastic process $\{X(t): t \geq 0\}$, as a model of the process of engine state transitions can be simplified due to $p_{23}=$ 0 , and thus there is no function $Q_{23}(t)(8)$.

\section{Simplified semi-Markov models of engine technical state transition}

Currently applied diagnosing systems $(S D G)$ for identifying the technical condition of marine main engines considered as diagnosed systems $(S D N)$, such as Cocos (Con-trolled Computer Surveillance System) of MAN company, or CBM (ConditionBased Maintenance) of Wartsila company [27, 28, 29] are designed to disclose the most important states classified as $s_{2}$ for the engines [7, 9, 10, 11, $23]$. It can be assumed that occurrence of state $s_{2}$, is a result of damage to the engine. Such sort of damage allows further operation of the engine, but does not ensure performance of the task $Z_{d}$ which must be carried out. Disclosure by the $S D G$ of the state $s_{2}$ in the engine enables performance of some adequate preventive service and full engine recovery, and in consequence regaining of state $s_{1}$, that allows performance of the task $Z_{d}$. Despite using the $S D G$, damages to engines are reported during their operation. The technical state that results from such damage is recognized as $s_{3}$

When $p_{23}=0$, the model of the process of state transitions for main engines is a stochastic process $\{Y(t): t \geq 0\}$ with the set of states $S=\left\{s_{i} ; i=1,2\right.$, $3\}$ (6) and the graph of state transitions as depicted in Fig. 1. Transitions of the states proceed at the moments $\tau_{0}=0, \tau_{1}, \tau_{2}, \tau_{3}, \tau_{4}, \tau_{5}, \ldots, \tau_{n}$ (Fig. 2). Due to the fact that the process $\{Y(t): t \geq 0\}$ is a semiMarkov process, the moments are random variables which satisfy the condition:

$$
\begin{aligned}
& P\left\{Y\left(\tau_{n+1}\right)=s_{j}, \tau_{n+1}-\tau_{n}<\tau \mid Y\left(\tau_{n}\right)=s_{i}, Y\left(\tau_{n-1}\right), \ldots\right. \\
& \left.\ldots Y\left(\tau_{1}\right), Y\left(\tau_{0}\right), \tau_{n}-\tau_{n-1}, \ldots, \tau_{1}-\tau_{0}, \tau_{0}\right\}= \\
& =P\left\{Y\left(\tau_{n+1}\right)=s_{j}, \tau_{n+1}-\tau_{n}<\tau \mid Y\left(\tau_{n}\right)=s_{i}\right\}
\end{aligned}
$$

A graph of state transitions of the process $\{Y(t)$ : $t \geq 0\}$ and thus also of engine, is shown in Fig. 1 . This model of changing technical states of engine is a simplified model when comparing to the model in the form of the process $\{X(t): t \geq 0\}$. The simplification consists in that the function matrix (8) of the process $\{Y(t): t \geq 0\}$ does not take into account the function $Q_{23}(t)$, because $Q_{23}(t)=0$, due to the fact that $p_{23}=0$. 


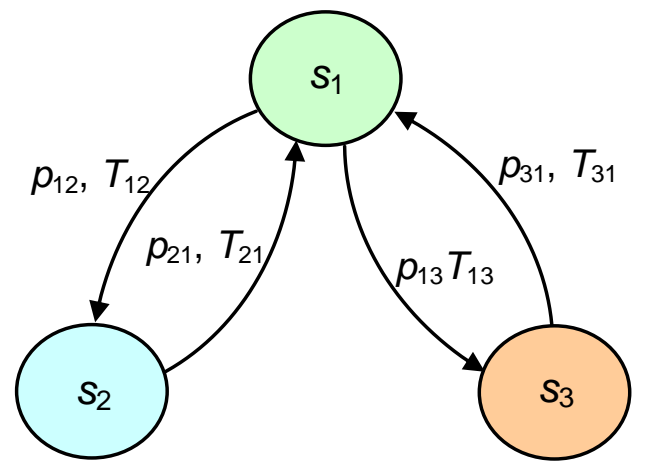

Fig. 1. Graph of engine state transitions: $p_{i j}$ - probability of engine transition from state $s_{i}$ to state $s_{j}, T_{i j}$ - duration of state $s_{i}$ if the process transits to state $s_{j} ; i \neq j ;$
$\quad i, j=1,2,3$

An example of the process $\{Y(t): t \geq 0\}$ is illustrated in Fig. 2

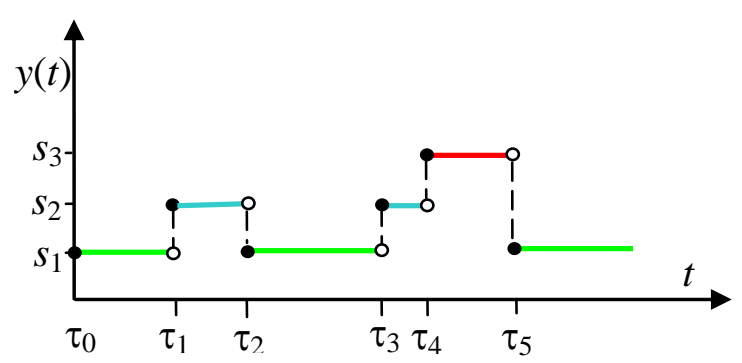

Fig. 2. An example of the process $\{Y(t): t \geq 0\}$ for an engine: $\{y(t): t \in T\}$ - process of technical state transitions, $t$-operating time; $s_{1}-$ state of full ability, $s_{2}-$ state of partial ability, $s_{3}-$ state of disability

Initial distribution of the process is defined by the formula (7), while its function matrix is as follows:

$$
\mathbf{Q}(\mathbf{t})=\left[\begin{array}{ccc}
0 & Q_{12}(t) & Q_{13}(t) \\
Q_{21}(t) & 0 & 0 \\
Q_{31}(t) & 0 & 0
\end{array}\right]
$$

The limiting distribution for the process $\{X(t): t$ $\geq 0\}$ can be derived from the formula [2, 11, 19, 24]:

$$
P_{j}=\frac{\pi_{j} \cdot E\left(T_{j}\right)}{\sum_{k=1}^{3} \pi_{k} \cdot E\left(T_{k}\right)}, j=1,2,3
$$

The distribution $\pi_{j}(j=1,2,3)$ in the formula (10) is a limiting distribution of the Markov chain $\left\{Y\left(\tau_{n}\right): n=0,1,2,3, \ldots\right\}$ embedded in the process $\{Y(t): t \geq 0\}$. This distribution, as it follows from the function matrix (9), satisfies the system of equations [19]:

$$
\left.\begin{array}{l}
{\left[\pi_{1}, \pi_{2}, \pi_{3}\right] \cdot\left\{\begin{array}{ccc}
0 & p_{12} & p_{13} \\
1 & 0 & 0 \\
1 & 0 & 0
\end{array}\right\}=\left[\pi_{1}, \pi_{2}, \pi_{3}\right]} \\
\pi_{1}+\pi_{2}+\pi_{3}=1
\end{array}\right\}
$$

The solution of the system of equations (11), when considering the formula (10), are the probabilities:

$$
P_{1}=\frac{E\left(T_{1}\right)}{H}, P_{2}=\frac{p_{12} \cdot E\left(T_{2}\right)}{H}, P_{3}=\frac{p_{13} \cdot E\left(T_{3}\right)}{H}
$$

while

$$
H=E\left(T_{1}\right)+p_{12} \cdot E\left(T_{2}\right)+p_{13} \cdot E\left(T_{3}\right)
$$

where:

$P_{1}, P_{2}, P_{3}-$ probabilities that diesel engine finds respectively in the states: $s_{1}, s_{2}, s_{3}$;

$\pi_{j}$ - limiting probability of a Markov chain embedded in the process $\{Y(t): t \geq 0\}$ that describes possibility of occurring state $s_{j}, j=1,2,3$;

$p_{i j}$ - probability of the process $\{Y(t): t \geq 0\}$ transition from state $s_{i}$ to state $s_{j}$; $E\left(T_{j}\right)$ - expected value of duration of state $s_{j}$.

When performance of the task by the main engine is possible only if it finds in the state of full ability (i.e. state $s_{1}$ ), its reliability is defined by the probability $P_{1}$. However, when the task can be performed by the main engine, even when it finds in a state of partial ability $\left(s_{2}\right)$, the reliability of the engine can be determined by the sum of probabilities of the two types of states.

Depending on the selected operation strategy, the even more simplified model of state transitions can be applied for main marine engines. As the ship safety is essential when performing the transport task, there are considered only two states: $s_{1}$ (state of full ability) and $s_{2 *}$ (state of disability), where $s_{2 *}$ $\equiv s_{2} \cup s_{3}$. In such case, the process $\{Z(t): t \geq 0\}$ with a two-element set of states: $s_{1}$ and $s_{2 *}$ will be the model of engine state transitions. For such a simple model of engine state transitions, the intensity function $\lambda_{i j}(t)$ of transition of the process $\{Z(t): t$ $\geq 0\}$ (so also transition of the engine) from $s_{i}$ to $s_{j}(i$ $\neq j ; i, j=1,2^{*}$ ) can be applied for calculating probabilities $P_{1}$ and $P_{2}$. Transition intensity functions $\lambda_{i j}(t)$ are the ratios of transition probabilities $p_{i j}$, referred to the time interval $\Delta t$, which they concern. Thus, the graph of state transitions of the process $\{\{Z(t): t \geq 0\}$, thus also the engine, has the form as depicted in Fig. 3. 


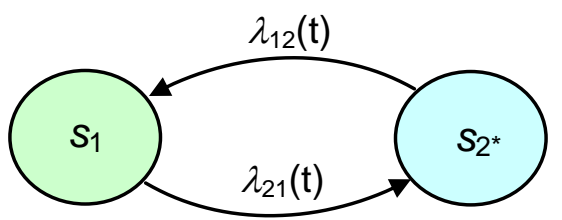

Fig. 3. Graph of engine state transitions: $\lambda_{i j}$ - probability of the process transition from stare $s_{i}$ to stare $s_{j} ;\left(i \neq j ; i, j=1,2^{*}\right)$

Due to the fact that the function $\lambda_{i j}(t)$ is a function of time $t$, thus dependent on $\Delta t$, therefore the relationship below is valid:

$$
\lambda_{i j}=\lim _{\Delta t \rightarrow 0} \frac{\lambda(t)}{\Delta t}=\text { const }
$$

The assumption in considerations that $\lambda_{i j}=$ const means that the process $\{Z(t): t \geq 0\}$ is a discrete-state continuous-time Markov model. This further means that random variables, which are the time of proper work of engine and the time of its renewal, are recognized as random variables with exponential distributions. Consideration of the time of proper work of engine as a random variable with exponential distribution is justified by the fact that in stormy weather conditions engines are subject to impact loads (so-called shock pulses) in particular $[2,26]$. Also probabilities of performing renewal to a damaged engine in time of storm are small and decrease with extending the time needed to do the renewal, which also makes it possible to assume that the renewal time is a random variable with exponential distribution [26]. Furthermore, the exponential distribution significantly reduces the values of engine reliability over time when comparing to other distributions of this sort of continuous random variables. In the proposed model, the intensity $\lambda_{12 *}$ of the process transition from state $s_{1}$ to state $s_{2 *}$ is called the risk function, and the transition intensity $\lambda_{2 * 1}$ - intensity function of renewal (restitution). In this case the probabilities $P_{1}$ and $P_{2}$ can be derived from the formulas [17]:

$$
\begin{aligned}
& P_{1}(t)=\frac{\lambda_{2 * 1}}{\lambda_{2 * 1}+\lambda_{12}}+\frac{\lambda_{12}}{\lambda_{12}+\lambda_{2 * 1}} \exp \left\{-\left(\lambda_{12}+\lambda_{2 * 1}\right) t\right\} \\
& P_{21}(t)=\frac{\lambda_{12}}{\lambda_{12}+\lambda_{12 *}}-\frac{\lambda_{12}}{\lambda_{12}+\lambda_{2 * 1}} \exp \left\{-\left(\lambda_{12}+\lambda_{2 * 1}\right) t\right\}
\end{aligned}
$$

When the operating time $t$ of engine is very long (in theory $\mathrm{t} \rightarrow \infty$ ), the formulas (14) take the forms:

$P_{1}(t)=\frac{\lambda_{2 * 1}}{\lambda_{2 * 1}+\lambda_{12}}$ oraz $P_{21}(t)=\frac{\lambda_{12}}{\lambda_{12}+\lambda_{12 *}}$

since in the formulas (16) the values $\exp \{\bullet\}=0$.
When transportation tasks are carried out by ships in favorable conditions, so in the periods (seasons) in which there are no storms, it can be assumed that the random variable which is the time of proper operation of the engine, has a gamma distribution, and the random variable which is the engine renewal time - normal distribution. Then, it can be assumed that [2]:

$$
\lambda_{12}(t)=\frac{\lambda_{12}^{r} t^{r-1}}{(r-1) !\left[1+\frac{1}{1 !} \lambda_{12} t+\frac{1}{2 !}\left(\lambda_{12} t\right)^{2}+\ldots+\frac{\left(\lambda_{12} t\right)^{r-1}}{(r-1) !}\right]}
$$

where: $r$-parameter of distribution shape.

With the growth of $t(t \rightarrow \infty)$ the function (16) increases monotonically to $\lambda_{12}=$ const $[2,26]$. The function $\lambda_{2 * 1}$, whereas, is defined by the formula [2]:

$$
\lambda_{2 * 1}(t)=\frac{1}{\sqrt{2 \pi} \sigma \Phi\left(\frac{m_{1}-t}{\sigma}\right)} \exp \left\{-\frac{\left(t-m_{1}\right)^{2}}{2 \sigma^{2}}\right\}
$$

where:

$\sigma-$ standard deviation, $m_{1}-$ zero moment of the first order (expected value),

$$
\Phi\left(\frac{m_{1}-t}{\sigma}\right)-\text { Laplace function. }
$$

With the growth of $t$ the function (17) increases monotonically $[2,26]$.

The probabilities defined by the formulas (12), (14) and (15) are significant in the phase of planning the engine operation whose implementation requires securing the funds, fuel supply and lubricating oil, and spare parts. However, the phase of engine operating requires controlling the process of changes in engine technical condition, which consists in making decisions. This requires knowledge of reliability of diagnosis on the engine technical state and consequences of making a decision selected from among possible decisions in the given operating situation for this kind of engines [14, 15, 16]. Optimal decisions can be made when applying semi-Markov decision (controlled) processes or statistical decision theory. From among the theories, Bayesian statistical decision theory is easier for use. In this theory a criterion of decisionmaking is an expected value of decision consequences. According to this criterion, making an operating decision consists in selecting the optimal decision belonging to the set of possible decisions in the given operating situation. Such a decision is always this one which the highest expected value of consequences corresponds to [1]. Application of Bayesian statistical decision theory requires development of a statistical model of decision-making. 


\section{Statistical model of decision-making}

Application of an appropriate diagnosing system $(S D G)$ for identifying technical condition of a main engine as diagnosed system $(S D N)$, allows obtaining a diagnosis on technical state of the engine, with defined reliability. A measure of diagnosis reliability is the conditional probability $P\left\{s_{i} / \mathbf{K}_{\mathbf{i}}\right\}$, that the engine is in state $s_{i}$ provided that the value vector $\mathbf{K}_{\mathbf{i}}$ of diagnostic parameters corresponding to this state, is observed [13, 15]. This information and also the knowledge of consequences of each decision, enable application of the statistical decision theory for making a rational decision, e.g. from the following two possible $[14,16]$ :

- decision $d_{1}$ - perform first an adequate preventive maintenance of engine to renew its state, which is indispensable to carry out the task $Z_{d}$, and then, start performing the task according to the schedule set by the customer.

- decision $d_{2}-$ do not perform the maintenance service and start performing the ordered task $Z_{d}$

The Bayesian statistical decision theory shows that in such a decision situation, e.g. for the process $\{Z(t): t \geq 0\}$ of changing engine technical states, considerations should include decision dendrite as demonstrated in Fig. 4.

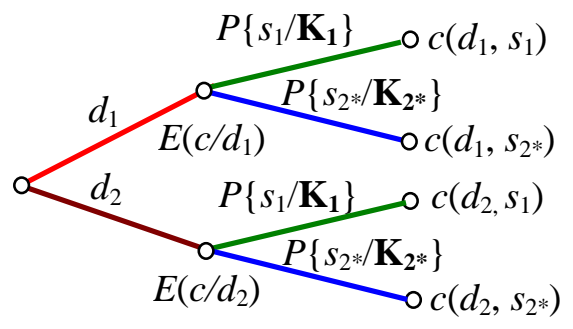

Fig. 4. Decision dendrite for making decision $d_{1}$ or $d_{2}: d_{1}-$ decision to perform first the appropriate preventive maintenance to the engine and then the given task, $d_{2}$ - decision to perform the ordered

task without prior preventive maintenance to the engine,

$P\left\{s_{1} / \mathbf{K}_{1}\right\}$ - probability that engine is in state $s_{1}$, provided that vector $\mathbf{K}_{\mathbf{1}}$ of diagnostic parameters is observed,

$P\left\{s_{2^{*}} / \mathbf{K}_{\mathbf{2}}\right\}$ - probability that engine is in state $s_{2^{*}}$, provided that vector $\mathbf{K}_{\mathbf{2}}$ of diagnostic parameters is observed,

$c\left(d_{1}, s_{1}\right)$ - consequence of decision $d_{1}$ when engine state is $s_{1}, c\left(d_{1}, s_{2 *}\right)$ - consequence of decision $d_{1}$ when engine state is $s_{2^{*}}, c\left(d_{2}, s_{1}\right)$-consequence of decision $d_{2}$ when engine state is $s_{1}, c\left(d_{2}, s_{2 *}\right)-$ consequence of decision $d_{2}$ when engine state is $s_{2 *}$

The decision dendrite provided in Fig. 4 indicates that the expected values can be derived from the following relationships $[14,15]$ :

$$
\left.\begin{array}{l}
E\left(c \mid d_{1}\right)=P\left(s_{1} \mid \mathbf{K}_{1}\right) c\left(d_{1}, s_{1}\right)+P\left(s_{2^{*}} \mid \mathbf{K}_{2}\right) c\left(d_{1}, s_{2^{*}}\right) \\
E\left(c \mid d_{2}\right)=P\left(s_{1} \mid \mathbf{K}_{\mathbf{1}}\right) c\left(d_{2}, s_{1}\right)+P\left(s_{2^{*}} \mid \mathbf{K}_{\mathbf{2}}\right) c\left(d_{2}, s_{2^{*}}\right)
\end{array}\right\}
$$

where the below relationship is valid:

$$
P\left(s_{1} \mid \mathbf{K}_{1}\right)+P\left(s_{2 *} \mid \mathbf{K}_{2 *}\right)=1
$$

In accordance with the decision-making rule, decision $d_{1}$ should be made when $E\left(c \mid d_{1}\right)>E\left(c \mid d_{2}\right)$, and inversely - decision $d_{2}$. should be made when $E\left(c \mid d_{1}\right)<E\left(c \mid d_{2}\right)$.

Probabilities $P\left(s_{i} / \mathbf{K}_{\mathbf{i}}\right)$ as measures of reliability of diagnosis can be derived from the dependence [14]:

$$
P\left(s_{i} \mid \mathbf{K}_{\mathbf{i}}\right)=\frac{P(A) P\left(s_{i} \mid A\right) P\left(\mathbf{K}_{\mathbf{i}} \mid A \cap s_{i}\right)}{P\left(\mathbf{K}_{\mathbf{i}}\right) P\left(A \mid \mathbf{K}_{\mathbf{i}} \cap s_{i}\right)}
$$

where: $P\left(s_{i} / \mathbf{K}_{\mathbf{i}}\right)$ - probability that engine is in state $s_{i}\left(i=1,2^{*}\right)$, provided that the value vector $\mathbf{K}_{\mathbf{i}}$ of diagnostic parameters is observed, $A-$ an event that $S D G$ works properly, $P(\mathrm{~A})$ - probability of proper work of $S D G, P\left(s_{i} / A\right)$ - probability that engine is in state $s_{i}\left(i=1,2^{*}\right)$, provided that $S D G$ works properly, $P\left(\mathbf{K}_{\mathbf{i}} / A \cap s_{i}\right)$ - probability that the value vector $\mathbf{K}_{\mathbf{i}}$ of diagnostic parameters is observed, provided that $S D G$ works properly and the engine is in state $s_{i}$, $P\left(\mathbf{K}_{\mathbf{i}}\right)$ - probability that the value vector $\mathbf{K}_{\mathbf{i}}$ of diagnostic parameters is observed, $P\left(A / \mathbf{K}_{\mathbf{i}} \cap s_{i}\right) \quad-$ probability that $S D G$ works properly, provided that the value vector $\mathbf{K}_{\mathbf{i}}$ of diagnostic parameters is observed and the engine is in state $s_{i}$

Assuming that $P(A)=1$, the formula (19) can be simplified to the following form [14]:

$$
P\left(s_{i} / \mathbf{K}_{\mathbf{i}}\right)=\frac{P\left(s_{i}\right) P\left(\mathbf{K}_{\mathbf{i}} / s_{i}\right)}{P\left(\mathbf{K}_{\mathbf{i}}\right)}
$$

which allows obtaining a measure of diagnosis accuracy.

Considering the measures of diagnosis reliability (19) or accuracy (20) in engine diagnostics allows development of a rational operating diagnosis on engine ability to perform the task $Z_{d}[5,16]$.

\section{Final remarks and conclusions}

In research on reliability of engines a variety of mathematical models can be used, including more adequate functional models in the form of semiMarkov processes. Semi-Markov processes are increasingly applied, and not only for solving different issues regarding reliability and diagnostics of diesel or other combustion engines.

Application of a semi-Markov process as a model of changes in the mentioned reliability states of a main engine at defined time, results from that the random variable $T_{(i j)}$ denoting duration of state 
$s_{(i)}$, provided that the successive state is $s_{j}$, and the variable random $T_{i}$ denoting duration of engine state $s_{(i)}$ (e.g. $i=1,2,3$ or $i=1,2^{*}$ ), regardless of which state is successive, have distributions that belong in the set $R_{+}=[0,+\infty)$.

When using an appropriate $S D G$ enabling development of a complete diagnosis (instantaneous diagnosis, prognosis and genesis) with defined reliability $P\left(s_{i} / \mathbf{K}_{\mathbf{i}}\right)$, it makes sense to apply a twostate Markov process for studying this kind of engines, because in this case that includes additional requirement of ensuring a high safety level to a seagoing ship, it can be assumed that the random variables $T_{(i j)}$ and $T_{(i)}$ have exponential distributions.

The presented models can be of significant practical meaning due to the ease of defining the estimators of transition probabilities $p_{(i j)}$ and the ease of estimating the expected values $\mathrm{E}\left(T_{(j)}\right)$. Thereby, it should be considered that the point estimate of the expected value $\mathrm{E}\left(T_{(j)}\right)$ does not allow determining the accuracy of the estimation. Such accuracy is possible to provide by interval estimation, where the confidence interval $\left[t_{d(j)}, t_{g(j)}\right]$, with random limits is determined, which contains with a defined probability (confidence level) $\beta$, the unknown expected value $\mathrm{E}\left(T_{(j)}\right)$.

Moreover, consideration of reliability of the diagnosis $P\left(s_{i} / \mathbf{K}_{\mathbf{i}}\right)$ in the operating phase enables, by using the statistical decision theory, to make optimal operating decisions from among the possible decisions for main engines in the given operating situation.

It can reasonably be expected that the proposed models may also be useful in studies on reliability of other machines.

\title{
Abbreviations and terms
}

\author{
$p D G$ - complete diagnosis on engine technical state, \\ $S D$ - diagnostic system, $S D N$ - diagnosed system \\ $S D G$ - diagnosing system, $\mathrm{P}\left(\mathrm{s}_{i} / \mathbf{K}_{\mathbf{i}}\right)$ - probability being a measure \\ of diagnosis reliability
}

\section{References}

[1] Benjamin J.R., Cornell C.A.: Probability, Statistics, and Decision for Civil Engineers. Wyd. polskie Rachunek prawdopodobieństwa, statystyka matematyczna i teoria decyzji dla inżynierów. WNT, Warszawa 1977.

[2] Gercbach J.B., Kordonski Ch.B.: Modele niezawodnościowe obiektów technicznych. WNT, Warszawa 1968. Dane o oryginale: Герцбах И. Б.,Кордонский Х.Б.: Модели отказов. Советское Радио, Москва 1966.

[3] Girtler J.: Usefulness of semi-Markov processes as models of the operation processes for marine main engines and other machines of ship power plants. Journal of Polish CIMAC, Vol. 9, No. 2, 2014, pp.57-67.

[4] Girtler J.: Semi-Markov model of diesel engines' operating process. Archiwum Motoryzacji 2004, Vol. 7, Nr 3, s. 165-196.

[5] Girtler J.: Significance of technical diagnostics in decision control of combustion engines operation process. Archiwum Motoryzacji 2004, Vol. 7, Nr 4, s. 389-407.

[6] Girtler J.: Możliwości zastosowania i przydatność procesów semimarkowskich jako modeli procesów eksploatacji maszyn. Zagadnienia Eksploatacji Maszyn, Warszawa 1996, z.3(107) s. 419-428.
[7] Girtler J.: Diagnostyka jako warunek sterowania eksploatacją okrętowych silników spalinowych. Studia Nr 28, WSM, Szczecin 1997.

[8] Girtler J.: Physical aspects of application and usefulness of semi-Markov processes for modeling the processes occurring in operational phase of technical objects. Polish Maritime Research, Vol. 11, No 3, 2004, pp.. 25-30.

[9] Girtler J.: Quantum issues in diagnostics of marine energy machines and devices. Scientific Journals Maritime University of Szczecin. No 30(102).

[10]Girtler J.: Aspekty kwantowej diagnostyki maszyn. XXXIX Sympozjum Diagnostyki Ma-

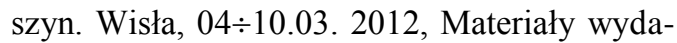
ne $\mathrm{w}$ formie streszczeń referatów i na CD, $23 \mathrm{~s}$. Wyd. Wydział Transportu Politechniki Śląskiej, Katowice 2012.

[11] Girtler J.: Stochastic model of Diesel engines' operating process. J. of KONES 2004 vol. 11, nr 1-2, pp. 178-188.

[12] Girtler J.: The semi-Markov model of energy state changes of the main marine internal combustion engine and method for evaluating its operation during ships voyage. Polish Maritime Research, Vol. 18, No. 4, 2011, pp. 36-42.

[13] Girtler J.: Diagnosis' likelihood and diagnosis rightness about the technical state of diesel en- 
gine. Proceedings of the III International Scientific-Technical Conference EXPLO DIESEL \& GAS TURBINE '03. Gdańsk-MiędzyzdrojeLund (Sweden), May 5-9, 2003. Gdańsk: Univ. Technol. Fac. Ocean. Eng. \& Ship Tech. 2003, pp. 215-221.

[14] Girtler J.: Zastosowanie wiarygodności diagnozy do podejmowania decyzji w procesie eksploatacji urządzeń. Materiały V Krajowej Konferencji Diagnostyka Techniczna Urządzeń i Systemów DIAG'2003. Ustroń, 13-17 października 2003. WAT, PAN, Warszawa 2003 s. 100-109.

[15] Girtler J.: Probabilistic measures of a diagnosis' likelihood about the technical state of transport means. Archives of Transport, Vol. 11, Iss. 3-4. Polish Academy of Sciences. Committee of Transport, pp.33-42.

[16] Girtler J.: Zastosowanie bayesowskiej statystycznej teorii decyzji do sterowania procesem eksploatacji urządzeń. Materiały XXII Zimowej Szkoły Niezawodności nt. Wartościowanie niezawodnościowe $\mathrm{w}$ procesach realizacji zadań technologicznych w ujęciu logistycznym. SPE KBM PAN, Szczyrk 1994, s.55-62.

[17] Girtler J.: Zastosowanie modelu Markowa w procesie sterowania eksploatacją urządzeń. III Szkoła Inżynierii Systemów, t. III, ITWL, Warszawa 1987, s. 155-176.

[18] Grabski F.: Semi-markowskie modele niezawodności i eksploatacji. PAN IBS, Seria: Badania Systemowe t. 30, Warszawa 2002.

[19] Grabski F.: Teoria semi-markowskich procesów eksploatacji obiektów technicznych. Zeszyty Naukowe AMW, nr 75A, Gdynia 1982.

[20] Korczewski Z.: Endoscopic image processing and analysis of piston's service failures of marine Diesel engines. Journal of Polish CIMAC, Vol. 6, No. 2, 2011, pp.125-134.

[21] Limnios N., Oprisan G.: Semi-Markov Processes and Reliability. Boston, Birkhauser 2001.

[22] Piotrkowski I., Witkowski K.: Eksploatacja okrętowych silników spalinowych. AM, Gdynia 2002.

Prof. Jerzy Girtler - full professor in the Faculty of Ocean Engineering of Ship technology at Gdansk University of Technology.

Prof. dr hab. inż. Jerzy Girtler profesor zwyczajny na Wydziale Oceanotechniki $i$ Okrętownictwa Politechniki Gdańskiej.
[23] Rudnicki J.: Usage of semi-Markov process in operation evaluation of Diesel engine. Journal of Polish CIMAC, Vol. 5, No. 2, 2010, pp. $151-160$

[24] Сильвестров Д. С.: Полумарковские процессы с дискретным множеством состояний. Издательство „Советское Радио". Москва, 1980.

[25] Inżynieria diagnostyki maszyn. Praca zbiorowa pod redakcją B. Żółtowskiego i C. Cempla. PTDT. Wyd. ITE, Warszawa, Bydgoszcz, Radom 2004.

[26] Poradnik niezawodności. Praca zbiorowa pod redakcją J. Migdalskiego. Wydawnictwa Przemysłu Maszynowego „WEMA”, Warszawa 1982.

[27] MAN B\&W Diesel A/S: CoCoS Maintenance, Designed for Maintenance Excellence, Kopenhaga 2005.

[28] Wärtsilä Corporation: Service News from Wärtsilä Corporation 2 2002/1 2003, CBM for two stroke engines, Kaidara Software, Wartsila Corporation Helsinki, marzec 2003.

[29] Girtler J., Fydrych J.: Analiza i ocena przydatności opracowanego systemu diagnostycznego silników głównych statków do sterowania procesem eksploatacji tego rodzaju silników w aspekcie zapewnienia bezpieczeństwa statków oraz morskiego środowiska naturalnego. Sprawozdanie $\mathrm{z}$ etapu realizacji projektu badawczego własnego nt. „Decyzyjne sterowanie procesem eksploatacji układów korbowotłokowych silników napędu głównego statków morskich z zastosowaniem diagnostyki technicznej oraz uwzględnieniem bezpieczeństwa i ochrony środowiska." Projekt wykonywany w ramach projektu finansowanego przez MNiSW Nr N N509 494638. Kierownik projektu prof. dr hab. inż. Jerzy Girtler. Prace badawcze nr 04/12/PB. Wydział Oceanotechniki i Okrętownictwa Politechniki Gdańskiej, Gdańsk 2012. 